\title{
PROFESOR RYSZARD ANTONIEWICZ (1939-2015)
}

\section{Antoni Smoluk, Elżbieta Szlachcic}

DOI: $10.15611 / \mathrm{dm} .2016 .13 .11$.

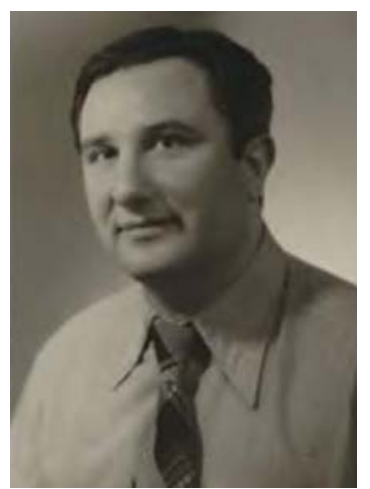

Niewątpliwie matematyka jest poezją, i to poezją najwyższego lotu. Gdy uczeń Dawida Hilberta wszechstronnie utalentowanego, wybitnego matematyka niemieckiego - dobrze zapowiadający się matematyk, porzucił matematykę i oddał się poezji, jego nauczyciel zauważył: widocznie miat za mała wyobraźnię, aby pracować $w$ matematyce. Istotnie, uprawiać matematykę można tylko przy dużej poetyckiej wyobraźni, malarskiej fantazji i muzycznym odczuciu, nie licząc wielkiej pracowitości, systematyczności i pedanterii. Świat matematyki jest także światem sztuki. Nauka i sztuka w swych najgłębszych warstwach tworzą jedność. Jednoczy je wyobraźnia twórcy, dzieli sposób percepcji. Naukę należy zrozumieć, aby odczuć jej piękno i wielkość. Profesor Antoniewicz uważał matematykę za naukę o świecie fizycznym, podobnie jak inne nauki przyrodnicze. Cechą charakterystyczną nauki jest utożsamianie struktur izomorficznych. Liczy się schemat, a nie nazwy poszczególnych elementów. Matematyka poprzez izomorfizmy jest szczytem wieńczącym piramidę naukową. Izomorfizmy to najpiękniejsza i najtrudniejsza zarazem część matematyki. Izomorfizmy rodzą abstrakcje, a abstrakcja dla ludzi zwyczajnych jest pustką. Dla matematyka ciąg algebraiczny jest tym samym co ciąg geometryczny, chociaż dla bankiera są to pojęcia całkowicie odmienne.

Odę do macierzy odwrotnej napisał w styczniu 1991 r. Arkadiusz Wojtowicz - wówczas student pierwszego roku Wydziału Zarządzania i Informatyki Akademii Ekonomicznej we Wrocławiu. Wiersz ten jest hołdem złożonym nauce oraz profesorowi Ryszardowi Antoniewiczowi za jego

\footnotetext{
Antoni Smoluk, Elżbieta Szlachcic

Department of Mathematics and Cybernetics, Wrocław University of Economics math@ue.wroc.pl
} 
teatralnie piękne wykłady $\mathrm{z}$ algebry liniowej. Wykładał on bowiem tak, jak zalecał swym aktorom odtwarzać sztukę teatralną wielki Stanisławski. Aktor nie grał, lecz przeżywał dramat. Profesor Antoniewicz tworzył na wykładzie nową rzeczywistość, był emocjonalnie zaangażowany w treść wypowiedzi, cieszył się pięknem tworzonych struktur i tą swoją radością zarażał słuchaczy; student bierze udział w boskim akcie tworzenia. Wiersz pana Arkadiusza Wojtowicza jest dowcipny, jednocześnie mądry i piękny.

\section{ODA DO MACIERZY ODWROTNEJ \\ PRZEKSZTAŁCENIA LINIOWEGO \\ (Arkadiusz Wojtowicz) \\ Algebro!!!}

Królowo nauk matematycznych!

Kocham Cię!

Czyż może być

Coś równie trudnego

I nierozwiązalnego

Jak źle zawiązane z dżdżownicy

Sznurowadło?!

Uczniu!!! Uczennico!!!

Wróć!? Nie odchodź od książki.

Wróć do macierzy jako

Ziemie zachodnie przed laty.

Wpij się w nią jak krwiożerca,

Jak krwiopijca wyssaj z niej wszystko!

Bądź bezwzględny, jak ta wartość niedawno

Przekształcona w normę Euklidesową.

Każde przekształcenie ma swą macierz,

Nie odrzucaj jej miłości macierzyńskiej.

Znajdź bazę, rozwiąż układ równań,

Oblicz pierwiastki, wykaż podobieństwo,

Udowodnij istnienie wymiaru

I zbadaj niezbadane wyroki,

Sięgaj, gdzie myśl nie sięga,

Sięgaj do $n$-tego wymiaru,

Znajdź rząd, dodaj, odejmij,

Pomnóż, zamień wiersz, kolumnę,

SPROWADŹ DO POSTACI, ODWRÓĆ!!!

...Samo życie... Sens istnienia...

Autor doskonale uchwycił podstawowy problem algebry liniowej. Jest nim odpowiedź na pytanie, kiedy dwie macierze reprezentują, w różnych bazach, tę samą operację liniową. Aby napisać taki wiersz, należy dobrze zrozumieć 
istotę algebry liniowej. Liczy się głęboka i szeroka wiedza. Prawdziwe studia dają rozległe horyzonty. Dyrektor największego polskiego banku na pytanie, jakiego absolwenta widzi u siebie, odpowiada bez wahania: $C z ł o-$ wieka renesansu. Bankowości naucze go w pół roku [Eurostudent 53, luty 2001, s. 5]. Człowiek renesansu był artystą i uczonym, był matematykiem i poetą.

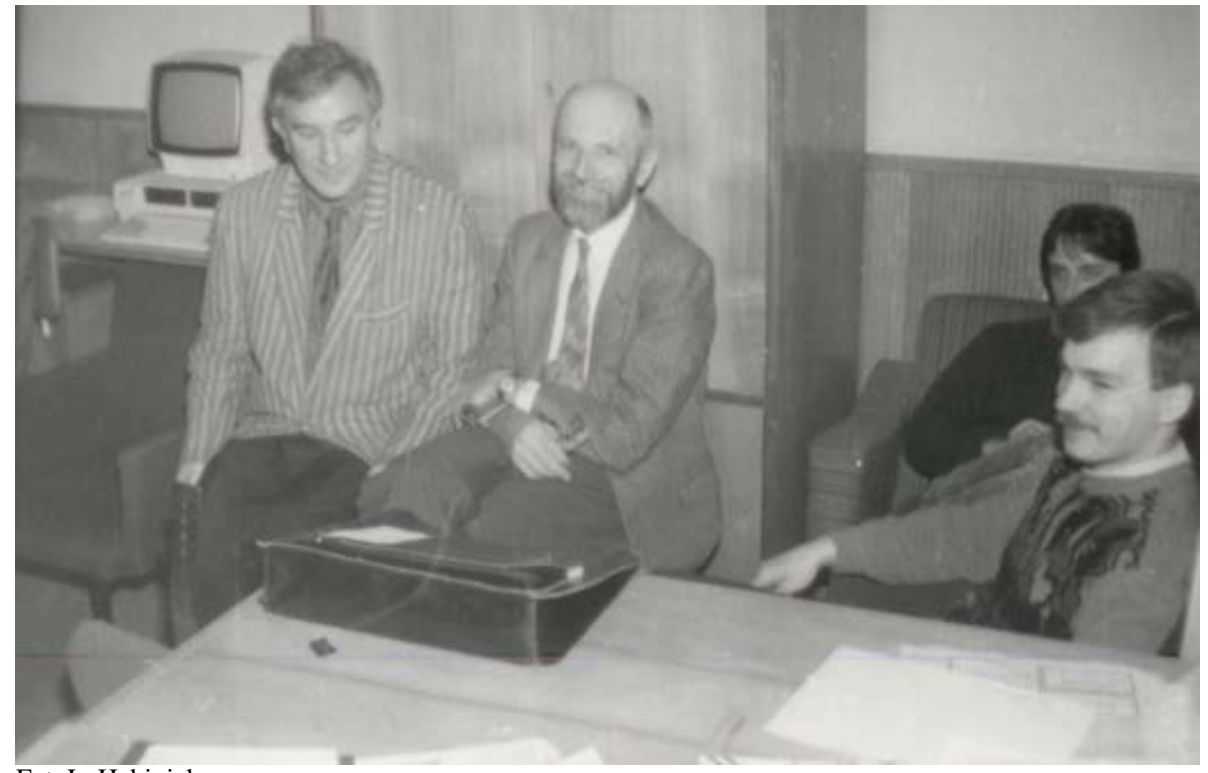

Fot. L. Habiniak

Seminarium dydaktyczne Katedry Matematyki, 11 kwietnia 1991, budynek B, sala 10b. Od lewej: R. Antoniewicz, A. Smoluk, J. Łyko, A. Misztal

Urodził się 19 sierpnia 1939 roku w Werenowie. Studia na wydziale Mat-Fiz-Chem. Uniwersytetu Wrocławskiego ukończył w 1964 roku, uzyskując tytuł magistra fizyki za pracę Teoria estymacji a teoria informacji. Po studiach podjął pracę w Instytucie Fizyki Teoretycznej PAN. Doktoryzował się 1973 roku na Wydziale Mat-Fiz-Chem. Uniwersytetu Mikołaja Kopernika u profesora Romana Ingardena. Przedstawił rozprawę doktorską Temperatury wyższych rzędów w uogólnionej termodynamice statystycznej promieniowania koherentnego $w$ wyższym rzędzie. Od 1973 roku, po uzyskaniu doktoratu na Uniwersytecie Toruńskim, pracował w Katedrze Statystyki, a następnie Katedrze Matematyki Akademii Ekonomicznej we Wrocławiu. Habilitował się w 1989 uzyskując stopień doktora habilitowanego nauk ekonomicznych na Wydziale Zarządzania i Informatyki Akademii 
Ekonomicznej we Wrocławiu. Jego rozprawa habilitacyjna z 1988 roku pt. Metoda najmniejszych kwadratów dla zależności niejawnych i jej zastosowania $w$ ekonomii poświęcona była uogólnionej metodzie najmniejszych kwadratów. Do chwili przejścia na emeryturę w roku 2007 jest profesorem uczelnianym w Katedrze Matematyki Uniwersytetu Ekonomicznego we Wrocławiu. Jako emeryt pracuje do chwili śmierci w Wyższej Szkole Zarządzania w Wałbrzychu. Umiera 20 lutego 2015 roku w szpitalu we Wrocławiu. Spoczął na cmentarzu we Wschowie. Otrzymał nagrodę ministra za rozprawę habilitacyjną oraz za podręcznik napisany wspólnie z Józefem Magierą Wstęp do algebry dla ekonomistów. Znany jest w całej Polsce podręcznik napisany wspólnie z Andrzejem Misztalem, Matematyka dla studentów ekonomii. Wykłady z ćwiczeniami wydany w 2000 roku przez Państwowe Wydawnictwo Naukowe. Oba te podręczniki z algebry i matematyki wyróżniają się swoistym wykładem; autorzy ich, a szczególnie profesor Antoniewicz, widzieli w matematyce naukę o świecie fizycznym, a nie abstrakcyjne rozważania o obiektach pomyślanych. Profesor Antoniewicz $\mathrm{w}$ swych badaniach poszukiwał prawd nauki, a formalizm był dla niego wtórnym dopełnieniem całości.

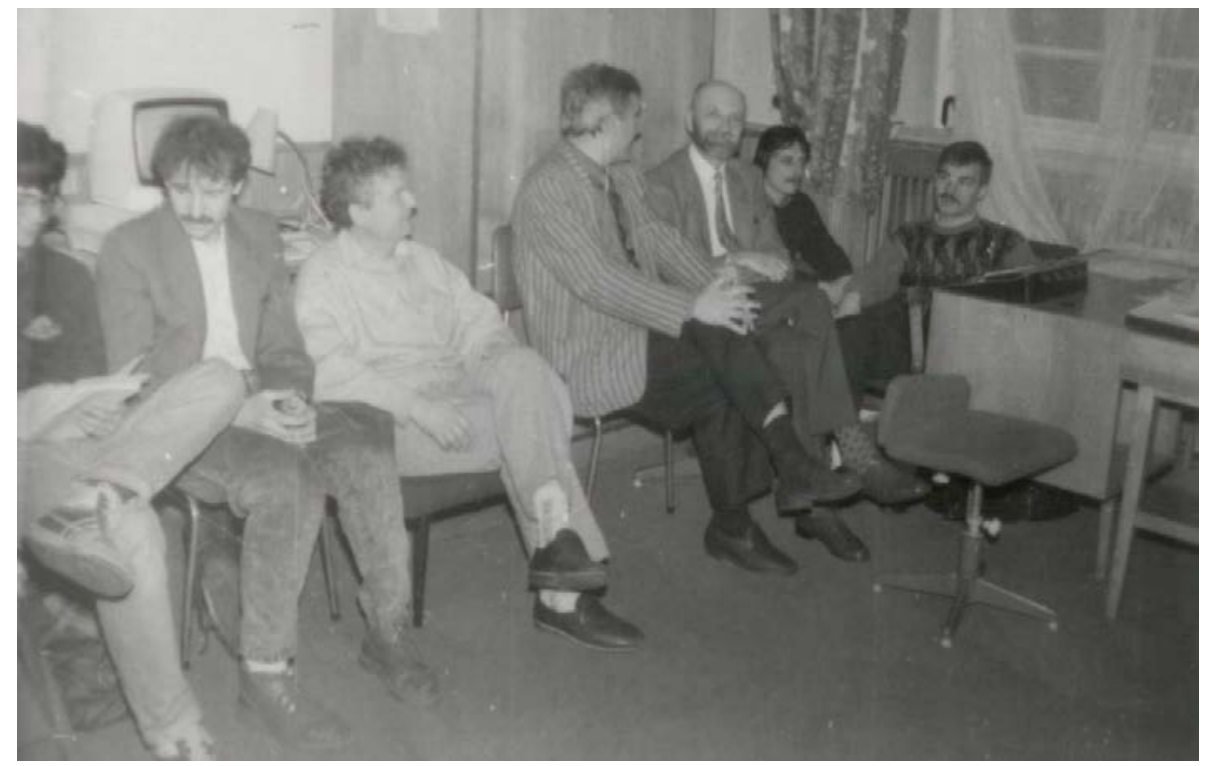

Fot. L. Habiniak

Seminarium dydaktyczne Katedry Matematyki, 11 kwietnia 1991, budynek B, sala 10b. Od lewej: M. Biernacki, G. Mielczarek, T. Janaszak, R. Antoniewicz, A. Smoluk, J. Łyko, A. Misztal 
Chociaż był fizykiem z wykształcenia i w swym doktoracie badał zastosowanie języka krat do opisu cząstek elementarnych, to jednak ulubionym przedmiotem była dla niego matematyka. Po kilkuletnim okresie pracy w Katedrze Statystyki Akademii Ekonomicznej we Wrocławiu przeszedł do Katedry Matematyki, gdzie wykładał przez wiele lat algebrę liniową na kierunku ekonometrycznym. Wspólnie z doktorem Józefem Magierą napisał krótki, ale bogaty $\mathrm{w}$ treść podręcznik algebry ogólnej, natomiast $\mathrm{z}$ doktorem Andrzejem Misztalem - wielokrotnie wznawiany podręcznik matematyki dla studentów uczelni ekonomicznych. Ta ostatnia książka jest podzielona na 26 jednostek dydaktycznych - wykładów. Miał dar dosadnego opisu typowych sytuacji życiowych. Jego teoria szwagra - wzór do naśladowania podsuwany przez żonę - zyskała w polskim środowisku ekonometrycznym zasłużony rozgłos. W czasopismach naukowych pojawiło się wiele prac dotyczących wzorców rozwoju i czynników wpływających na tempo rozwoju i rodzaj konsumpcji. Wszystkie publikacje tyczące się wyboru wzorca podsumował swoją kapitalną teorią szwagra. Małżonka wymusza, ciągłym powtarzaniem, by wzorować się na szwagrze. Rodzina szwagra bowiem ma wszystko: dom, dobry samochód, corocznie spędza wakacje w kurortach zagranicznych.

Profesor Rudolf Hohenberg, trzeci w kolejności kierownik Katedry Matematyki Wyższej Szkoły Ekonomicznej we Wrocławiu, w wolnych chwilach malował udane pejzaże. Kilka obrazów pozostało w spadku po nim w Katedrze. Z przyjemnością i zadowoleniem zaopiekował się nimi Ryszard; lubił sztukę. Część prac prezentowanych na wystawach Matematy$k a$ i sztuka, organizowanych w ubiegłych latach dwukrotnie na uczelni, przechowywał także w swoim gabinecie. Były to obrazy przedstawiające siodło - punkt równowagi ekonomicznej i powierzchnię jednostronną butelkę Kleina. Podobała mu się bardzo kompozycja przestrzenna: deska, gwoździe i sznurki, dobrze modelująca powierzchnię utkaną z linii prostych. Jego gabinet, po łagodnym upadku systemu sprawiedliwości społecznej, zapełnił się popiersiami wodzów proletariatu. Były to metalowe popiersia Lenina, Dzierżyńskiego, były to proporce i flagi sławiące pierwsze państwo socjalistyczne. Lubił abstrakcję, szukał prawa rządzącego rozmieszczeniem planet wokół Słońca. Wzorem dla niego była reguła Titiusa, rozpowszechniona przez Bodego i stąd często znana pod tymi dwoma nazwiskami. Reguła Titiusa i Bodego jest rozkładem planet Układu Słonecznego. Średnie odległości tych planet od Słońca, mierzone jednostką astronomiczną, można zapisać prostym wzorem będącym połączeniem ciągu arytmetycznego 
z geometrycznym. Jednostką astronomiczną jest średnia odległość Ziemi od Słońca równa w przybliżeniu 150 milionów kilometrów.

Jakie prawo rządzi słonecznym układem planetarnym? Tego nie wiemy do dziś, nawet po odkryciach Newtona i Laplace'a. Profesor Antoniewicz próbował wyjaśnić odległości pomiędzy planetami jakąś ogólną regułą uogólnieniem propozycji Titiusa i Bodego. Podejrzewał, że pierwiastki pewnych wielomianów ortogonalnych wyznaczają miejsca położenia planet. Czy nasz układ planetarny powstał ze spiralnego obłoku? Jeśli tak, to istnieje ogólne prawo rozkładu planet. Nauka szuka praw ogólnych, a profesor Ryszard Antoniewicz niewątpliwie należał do rozpoznawalnych ludzi nauki. 